\title{
Sexual Relations Between Psychotherapists and Their Patients: Toward Research or Restraint
}

\author{
Leonard L. Riskin $†$
}

\section{INTRODUCTION}

Many psychotherapists have sexual relations with their patients. This practice persists despite unbending condemnation by professional organizations, hicensing authorities, courts, and most of the psychotherapists who have written on the matter. Lately, however, a few therapists publicly have questioned the desirability of absolute bans. A small nunber have even argued that the activity can have therapeutic value. This intraprofessional conflict is troublimg because neither position is supported by rehable information about the inpact of therapistpatient sexual intimacy. Furthermore, existing social control devices almost ensure that this state of ignorance will continue.

What follows is an exploration of how society should treat sexual activity between psychotherapists and their patients. Although such behavior occurs in other professions, ${ }^{1}$ this Article centers on psychotherapists for three reasons: first, due to the einotional closeness that they develop with patients, psychotherapists nay be particularly tempted to engage in sexual activity; ${ }^{2}$ second, the saine emotional

$\dagger$ Professor of Law, University of Houston College of Law. B.S. 1964, University of Wisconsin; J.D. 1967, New York University School of Law; L.L.M. 1974, Yale Law School.

I. See W. Masters \& V. Johnson, Human Sexual Inadequacy 389 (1970) [hcreinafter cited as MASTERs \& JOHNSON]. In a 1973 study in which survey instruments were sent to 1,000 male physicians in Los Angeles County, there was no statistically significant difference in the extent of sexual activity reported by persons in various specialties, but psychiatrists and obstetricians reported greater apprehension of erotic contact because of thcir belief that such contact would be misinterpreted. Kardener, Fuller, \& Mensch, $A$ Survey of Physicians' Attitudes and Practices Regarding Erotic and Nonerotic Contact With Patients, 130 AM. J. Psychiatry 1077, 1080 (1973).

2. Marmor, Sexual Acting Out in Psychotherapy, 32 Am. J. PsychoAnalysis 3 (1972) [hercinafter cited as Marmor 1972]; Marmor, The Seductive Psychotherapist, 31 PsYcr. Dio. 10, 11 (Oct. 1970) [hereinafter cited as Marmor 1970].

Sigmund Freud considered the temptation toward sexual intimacy to be a frequent outgrowth of "the transference." That term describes a stage of psychoanalytic treatment in which the pa- 
closeness may make patients especially vulnerable to a therapist's advances and may increase the potential for harmful effects; ${ }^{3}$ third, and perhaps most important, in recent years some disagreement has developed within the profession as to the propriety of existing ethical proscriptions. ${ }^{4}$

The scope of this Article is limited to discussion of overt sexual relationships between adult, competent patients and properly trained and licensed psychotlerapists. ${ }^{5}$ Further, only relationships that take place ostensibly as part of the therapy, or contemporaneously with therapy are considered. ${ }^{6}$ The problem is set out in Part I. In Part II, current social control devices are described and criticized for their failure in deterring the activity and their success in inhibiting the production of information about it. Part III suggests an alternative community policy, and Part IV proposes a means of carrymg out that policy.

tient transfers to the analyst childhood feelings for an important person in her life, usually a parent. The analyst concurrently experiences compleinentary feelings, usually of love, known as "countertransference." S. Freud, Observations on Transference-Love (Further Recommendations on the Technigue of Psycho-Analysis III), in 12 THE STANDARd Edition OF THE CoMplete PsYChological Works of Sigmund Freud 157, 162 (J. Strachey ed. 1958).

3. $12 \mathrm{~S}$. Freud, supra note 2 , at 162.

4. See notes 19-25 and accompanying text infra.

5. All but a tiny percentage of the reported instances of therapist-patient sexual activity have involved a male therapist and a female patient. Perry, Physicians' Erotic and Nonerotic Contact With Patients, 133 AM. J. PsychlatRy 838, 840 (1976). Therefore, for convenience, the following discussion will use the male pronoun for the therapist and the female pronoun for the patient. This is not to suggest that analysis of the problem would be significantly different if the sexes were reversed, or if both parties were of the sane sex. But see Davidson, Psychiatry's Prob. lem With No Name: Therapist-Patient Sex, 37 AM. J. Psychoanalysis 43, 48 (1977).

A few instances of erotic contact between therapist and patient of the same sex have been reported. J. Goldstein, A. Dershowitz, \& R. Schwartz, Criminal LAw: Theory \& Process 5 (1974); M. Shepard, The Love Treatment 152-69, 170-98 (1971).

6. This Article does not consider sexual relations involving patients in psychiatric hospitals and similar institutions. Although sexual involveinent in such settings is likely to be reported up the chain of command, and may result in severe disciplinary action, see Stone, Management of Unethical Behavior in a Psychiatric Hospital Staff, 29 AM. J. PSYCHOTHERAPY 391, 399 (1975), it is far less likely to occur in those environments than in the solo practice setting where therapists are more autonomous. But see Anclote Manor Found. v. Wilkinson, 263 So. 2d 256 (Fla. Dist. Ct. App. 1972). Furthermore, proceedings within such an institution will provide hittle information, as they are not apt to come to public attention.

Sexual intimacy with patients who are incompetent, and similar activity annong persons doing (or purporting to do) psychotherapy in violation of licensing laws are also excluded here. For a discussion of these, see Peterson, State Finds Quacks in Mental Therapy, N.Y. Times, Dec. 7, 1972, $\S 1$, at 62 , col. 6. Further, such relations that commence shortly after psychotherapy has terminated are not discussed here. On this subject, see Finney, Therapist and Patient After Hours, 29 AM. J. Psychotherapy 593, 597 (1975); Voth, Love Affair Between Doctor and Patient, 26.AM. J. Psychotherapy 395, 396 (1972). Finally, this Article does not deal with treatment for sexual dysfunction in which sexual relations occur between a "surrogate" partner under the therapist's supervision, a technique pioneered by Masters and Johnson. See MASTERS \& JoHNSON, supra note 1 , at 146-54. 


\section{THE PROBLEM}

\section{A. The Conventional Wisdom}

"In every house where I come," states the Hippocratic oath, "I will enter only for the good of my patients, keeping myself far from all intentional ill-doing and all seduction, and especially from the pleasures of love with women and men."7

Most psychotherapists and major professional psychotherapists' associations have followed the conventional wisdom and have woodenly opposed sexual activity with patients. ${ }^{8}$ This opposition traditionally has been grounded upon utility, ethics, and public relations.

Sigmund Freud emphasized utility. He considered the patient's development of erotic interest im the therapist to be a useful part of the psychotherapeutic process because denial of these desires would demonstrate to the patient "the impossibility of conducting hife on the pleasure principle." $\mathrm{He}$ thus thought that any satisfaction of the patient's erotic interests was destructive of her "susceptibility to mfluence from analytic treatment. A combination of the two would be an impossibility."10

7. Stedman's Medical Dictionary 579 (22d ed. 1972). For an interesting exainple of a similar interdiction issued in the iniddle ages, see Braceland, Historical Perspectives of Ethical Practice, 126 AM. J. Psychiatry 230, 234 (1969).

8. Greenbank, Management of the Sexual Counter-Transference, 1 J. SEx RESEARCH 233 (1965); Hare-Mustin, Ethical Considerations in the Use of Sexual Contact in Psychotherapy, 11 PSYCHOTHERAPY: THEORY, RESEARCH \& PRACTICE 308 (1974); Lowry \& Lowry, Ethical Considerations in Sex Therapy, 1 J. MARR. \& FAM. Counselling 229 (1975); Marmor 1970, supra note 2; Redlicl, The Ethics of Sex Therapy, in EthiCal Issues in SeX THERAPY and Research 143 (W. Masters, V. Johnson, \& R. Kolodny eds. 1977).

The American Psychiatric Association states that "[s]exual activity with a patient is unethical" in the last sentence of an "annotation" to $\S 1$ of the Code of Ethics of the Ainerican Medical Association. An. Psychiatric Ass'n, Principles of Medical Ethics With Annotations Especially Applicable to Psychiarry, 130 Am. J. Psychiatry 1058, 1061 (1973). See also Am. Ass'N Of Sex EduCATORS, COUNSELORS \& THERAPISTS, CODE OF ETHICS FOR SEX THERAPISTS, Ethical Standard 4 (1975); Am. Psychoanalytic Ass'N, Principles of Ethics for Psychoanalysts and Provisions for IMPlementation of the PRINCIPles of Ethics for Psychoanalysts $§ 10$ (1975); Am. Psychological Ass'N, Ethical Standards of Psychologists, Primciple $6 a$ (1977 revision).

9. See S. Freud, Lines of Advance in Psycho-Analytic Therapy, in 17 The Standard Edition of the COMPLETE PSYCHOLOGiCAL WORKS OF Sigmund Freud 157, 164 (J. Strachey ed. 1955).

Freud contcnded that "abstinence" was a central requirement of psychoanalytic technique. "As far as [ler] relations with [ler] physician are concerned, the patient inust be left with unfulfillcd wishes in abundance." Id. He urged that the transference (see note 2 supra) should be exploitcd and the patient's desires frustrated to lielp overcoine resistance blocking the patient's way to knowledge of her subconscious. Development of erotic love for the analyst is "an expression of sucli resistance." 12 S. FReUd, supra note 2, at 162, 166.

10. $12 \mathrm{~S}$. FreUd, supra note 2, at 166. 
Freud also worried about the ethical problem, urging that the analyst should not obtain any "personal advantage" from the transference. ${ }^{11} \mathrm{He}$ was cognizant of contemporary moral standards ${ }^{12}$ and was deeply concerned about the reputation of his new technique. ${ }^{13}$

Most modern psychotherapists who have written about sexual contact between patients and their therapists also have opposed it categorically. For thein, and for the major professional psychotherapists' organizations that have issued absolute prohibitions of the activity, the main concern is that the therapist may lose his objectivity and exploit the patient. ${ }^{14}$ In addition, some commentators have emphasized such factors as the threat to social cohesion ${ }^{15}$ or the similarity to rape ${ }^{16}$ or to incest. ${ }^{17}$

Despite the long tradition of absolute proscription, however, many psychotherapists continue to be sexually involved with their patients. Over five percent of inale psychotherapists responding to two recent surveys admitted having been sexually intimate with patients during treatment. ${ }^{18}$

\section{B. Questioning the Conventional Wisdom}

Only one professional psychotherapist, James McCartney, has atteinpted squarely to make a case for sexual intimacy between therapists and patients. ${ }^{19}$ His publication of the fact that he had had sexual relations with many female patients as part of therapy, and his attempt to justify that behavior, resulted in his expulsion from the American Psychiatric Association. ${ }^{20}$

Subsequently, other therapists have challenged the bases of the traditional proscription less directly by stating that sexual activity with patients inay not always be harmful. Psychiatrist Clay Dahlberg, for exainple, has claimed that the nine cases of therapist-patient sexual in-

11. Id. at 169.

12. 3 E. Jones, The Life ANd WORK OF Sigmund Freud 165 (1957).

13. See 12 S. Freud, supra note 2, at 170. See also 2 E. Jones, The Life AND Work OF Sigmund Freud 108-09 (1955).

14. See note 8 supra.

15. Siassi \& Thomas, Physicians and the New Sexual Freedom, 130 AM. J. Psychiatry 1246, 1257 (1973).

16. Masters \& Johnson, Principles of the New Sex Therapy, 133 AM. J. PsYchiatRY 548, 553

(1976). See also Davidson, supra note 5, at 48. (1974).

17. Kardener, Sex and the Physician-Patient Relationship, 131 AM. J. Psychiatry 1134, 1135

18. Holroyd \& Brodsky, Psychologists'Atitudes and Practices Regarding Erotic and.Nonerotic Physical Contact With Patients, 32 AM. Psychologist 843 (1977); Kardener, Fuller, \& Mensch, supra note 1, at 1077.

19. McCartney, Overt Transference, 2 J. Sex Research 227 (1966).

20. D. Holmes, Psychotherapy 1010, 1011 (1972). See also West, Ethical Psychiatry and Biosocial Humanism, 126 AM. J. Psychiatry 226, 228 (1969). 
timacy of which he became aware during his practice ranged from "the relatively harmless to the frankly destructive."21

Some have suggested that it can be helpful. Psychiatrist Martin Shepard concluded from interviews with patients who engaged im sexual activity with therapists that "as many people are aided by intimate involvements with their therapists as are hurt."22 Psychologists Taylor and Wagner's 1976 survey of the literature indicated that the therapeutic results were positive for twenty-one percent of the patients who had been sexually involved with their therapists, inixed for thirty-two percent, and negative for forty-seven percent. ${ }^{23}$

Finally, a number of commentators have urged, in connection with therapy for specific sexual dysfunctions, that the profession simply does not have enough inforination to justify a blanket prohibition. Physician Mary S. Calderone, President of the Sex Information and Education Council of the United States, maintams that:

We have only opinions rather than facts with which to determine that it might or might not have value. But until we know more, rather than saying "no" or "it's bad," we should siniply say that we don't have enough information to say whether it's good or bad. ${ }^{24}$

Similarly, psychiatrist Jay Katz has argued that the ethics of therapistpatient sexual interaction deserve systematic study. ${ }^{25}$

21. Dahlberg, Sexual Contact Between Patient and Therapist, 6 Contemp. Psychoanalysis 107, 11 (1970). Cf. Robertiello, Iatrogenic Psychiatric Illness, 7 J. Contemp. Psychotherapy 3, 7 (1975).

22. M. SHEPARD, supra note 5, at 207.

On the basis of interviews with 11 patients who had sexual relations with their therapists, Shepard concluded that "intimacy with a therapist can indeed be useful," or "harmful," id. at 200, or a "diversionary waste of time." Id. at 201.

He went on to propose guidelines for both therapists and patients. For a critique of Shepard's approach, see Redlich, supra note 8 , at 150-51.

23. Taylor \& Wagner, Sex Between Therapists and Clients: A Review and Analysis, 7 ProfesSIONAL PSYCH. 593, 594 (1976).

24. Ethical Issues in Sex Therapy and Research 177 (W. Masters, V. Johnson, \& R. Kolodny eds. 1977) [hereinafter cited as ETHICAL IssuEs].

25. Id. at 161 .

But looking at it conceptually, I do not believe it to be a certainty that sexual intercourse with patients necessarily represents a conflict of interest. Do we know that sexual relations are harmful to sex therapy? Until we have gathered such knowledge, we need to ask what value preierences lead us to the conclusion that it is.

Id. at 179 (emphasis in original).

Even Dr. Williams Masters, who presses for the treatment of therapist-patient sexual intiinacy as statutory rape, Masters \& Johnson, supra note 16, at 553, admits that soine therapists who have sexual relations with their patients do so with integrity and retain their professional objectivity.

The greatest negation of professional responsibility is taking advantage of an essentially defenseless patient-but it often happens. . . . The difficulty is . . . that it's damn hard to be in bed and be objective at the same time. There are very few people who can do this with any success. . . . I don't think there can't be integrity . . . . I only think it's damn rare ... , of all the therapists, physicians, theologians, and behaviorists that are sleeping with their patients every day, certainly not more than five per cent have a great 


\section{The Need for Information}

The unqualified proscription of sexual relations between therapists and patients imposed by psychotherapists' professional organizations is based primarily on the assumption that a therapist who engages in such activity has lost, or will lose, his objectivity and will exploit and harm the patient. ${ }^{26}$ But there have been no systematic analyses of the ethical or utilitarian aspects of such behavior that could provide einpirical support for this and other assumptions behind the prohibition. Surveys of beliefs and practices have provided some indication of the frequency of the activity, ${ }^{27}$ but atteinpts to probe its effects and the circumstances under whicli it occurs have been retrospective and have suffered from severely biased and wildly variegated samples. ${ }^{28}$ Hypotheses were not made and tested, nor was there any follow-up, systematic or otherwise.

In recent years, lowever, a small but growing chorus of professionals has called for inquiry into actual practices and therapeutic results. ${ }^{29}$ If research is to avoid the weaknesses of existing studies, I believe it inust be prospective in significant part, not merely a survey of past events. Regardless of its outcoine, such research would make possible a forthright and rational evaluation of the desirability of therapist-patient sexual relations as a therapeutic tool. If it were shown that such relations can be beneficial in identifiable situations and can be conducted without exploiting the patient, their therapeutic, utilitarian value could be weighed against moral and ethical objections. ${ }^{30}$ If, on

deal of integrity involved. In which case it's pretty hard to accept it as a general premise and as a therapeutic approach.

M. SHEPARD, supra note 5, at 7-8.

26. See ethical statements cited in note 8 supra.

27. Holroyd \& Brodsky, supra note 18; Kardener, Fuller, \& Mensch, supra note 1; Perry, supra note 5.

28. Butler \& Zelen, Sexual Intimacies Between Psychotherapists and Their Patients, 14 PsyChotherapy: Theory, Research \& Practice 139, 143-44 (1977). See M. Shepard, supra note 5 .

29. M. ShePARD, supra note 5, at 7; Boas, Some Reflections on Sex Relations Between Physician and Patient 2 J. SeX ReseArCh 215, 218 (1966); Butler \& Zelen, supra note 28, at 143-44; Holroyd \& Brodsky, supra note 18, at 848-49.

Psychiatrist Clay Dahlberg wrote in 1970:

How many are there who do not complain-who do not feel that they are hurt or perhaps, as in McCartney's cases, even think they were helped by their therapists' sexual intervention? This is a worthwhile question and could be answered, at least in part.

What I am proposing is a Kinsey-type survey of therapists and patients to probe into the circumstances and results of sexual acting out and near acting out. What was the nature of the interpersonal dynamics when temptation was strong but not resisted, and what was the outcome? This would be a tough job, but it could be done.

Dahlberg, supra note 21 , at 123 .

30. It is obvious that in order to be useful, such an inquiry must go beyond questions concerning the boundaries of the existing proscriptions. It mnst include consideration of actual therapeutic outcomes in various situations, as well as by whom, and by what means sexual relations as a therapeutic device should be controlled. Finally, the inquiry must consider the compatibility of 
the other hand, the traditional assumptions were shown to be correct, the legitimacy of the bans would be increased and they might well become more effective. Unhappily, however, as Part II illustrates, existing methods of social control impede both the collection of basic information about existing practices and the conduct of prospective research.

\section{II}

\section{Social Controls}

Social control systeins often provide useful information about the behavior they regulate. The systems that deal with sexual relations between psychotherapists and patients, however, neither regulate nor inform. They clearly do not prevent the practice, ${ }^{31}$ and worse, as this section will show, they affirmatively impede the production of useful information about it. In each of the existing imstitutional frameworks discussed below, two phenomena are primarily responsible for these failures: first, deterrence is minimal because few cases are reported; and second, little information is generated about the activity because therapists are impelled to deny rather than to justify their behavior. As a result, the instances of therapist-patient sex that are exposed are mevitably among the worst cases and constitute a poor basis upon which to evaluate the activity. Most other cases are effectively hidden.

\section{A. Professional Organizations}

Although professional organizations tend to mete out severe sanctions against those therapists conclusively shown to have engaged in sexual relations with their patients, ${ }^{32}$ the deterrent effects of this policy are not substantial. Violations are rarely reported, and many professional organizations have neither the inclination nor the resources to pursue those that are. As a result, practitioners know that the disciphnary process is imvoked agamst only a small fraction of the offenders.

Reports to professional organizations are rare for several reasons. Patients generally will not report such incidents. Soune do not feel wronged, while others may experience mixed feelings of wrong, embarassinent, shame, or guilt, ${ }^{33}$ as do many rape victims. Some may fear

such an innovation with social norms, and the threat that it might pose to such valucs as patient dignity and popular (as well as internal) perceptions of the profession.

31. See text accompanying note 18 supra.

32. For example, the American Psychiatric Association expelled Janes McCartney for having sexual relations with a large number of female patients. D. HoLMES, supra note 20, at 1011.

33. Grunebaum, Nadleson, \& Macht, Sexual Activity With the Psychiatrist: A District Branch Dilemma (May 10-14, 1976) (unpublished paper presented to the American Psychiatric Association). 
that no one will believe them, or that the allegations will be made public. ${ }^{34}$ Some may even be reluctant to liarm their therapists, perhaps in part because they fear retaliation. ${ }^{35}$ If a patient overcoines these feelings and complaims to another therapist, several factors may prevent the complaint from being pursued. The therapist may not believe the patient. Even if he is satisfied that the allegations are true, he must decide whether to recommend that the patient lodge a formal complaimt. His decision slould depend, of course, only on whether such a course of action is im the patient's best interest. ${ }^{36}$ Instead, it may be colored by the therapist's loyalty to a colleague, or by his ignorance of the processes employed by the professional organization, the state licensing agency, and the courts, and hence, of his patient's chance of vindication. ${ }^{37}$ If a therapist receives his information froin the offending therapist, he may be bound by ethical constraints to keep it confidential..$^{38}$ Finally, regardless of the source of his information, he may be inclined to excuse the derelict therapist because that therapist is neurotic, disturbed, or old, or he simply may not bother to report an incident because it occurred in another part of the country. ${ }^{39}$

Once a coinplaint has been filed, the professional organization may have difficulty dealing with it. The district branches of the American Psychiatric Association, for example, typically have trouble getting inembers to sit on the ethics committee that performs the initial investigation, and lack both funds for legal representation and formal procedures for hearings. ${ }^{40}$ Professional organizations often are intimidated when members against whom charges have been filed appear with lawyers, threatening to sue. ${ }^{41}$

If an inquiry is pursued, the therapist alınost inevitably will deny, rather than try to justify his behavior. This is due primarily to the

34. See Sinnett \& Thetford, Protecting Clients and Assessing Malpractice, 6 ProfessionAL PSYCH. 117, 125 (1975).

35. Grunebaum, Nadleson, \& Macht, supra note 33, at 7-8. These factors are not, of course, created only by the procedures employed by professional organizations. In fact, they pervade all of the present institutional control systems.

36. $I d$.

37. See generally Stone, supra note 6 , at 395 . The therapist may not even have a clear understanding of the ethical principle involved, either because it was not stressed in his professional education, or because it has not been subjected to careful analysis.

38. See Am. Psychological Ass'n, Ethical STANDards of Psychologists, supra note 8, Principle 6; Am. Psychiatric Ass'n, Principles of Medical Ethics With Annotations Especially Applicable to Psychiatry, supra note 8, \$9.

39. Grunebaum, Nadleson, \& Macht, supra note 33, at 8.

40. Id. at 10; Stone, The Legal Implications of Sexual Activity Between Psychiatrist and Pa. tient, 133 AM. J. Psychiatry 1138, 1140 (1976).

41. See Stone, supra note 40, at 1140; Grunebaum, Nadleson, \& Macht, supra note 33, at 10. For a discussion of legal challenges that might be launched by an expelled therapist, see J. WALTZ \& F. INBAU, MEDiCAL JURISPRUdenCE 32-34 (1971). 
harshness with which those who have admitted the activity have been dealt, and the unwillingness of the profession to consider the possibility that therapist-patient sexual activity may be justifiable on therapeutic grounds. ${ }^{42}$

\section{B. Licensing Authorities}

State licensing bodies, which typically have authority to revoke the license of a physician or psychologist for "unprofessional conduct," "1nalpractice," or conviction of a crime involving "moral turpitude,"43 have exercised this power in several reported cases agamst psychotherapists who engaged in sexual activities with patients. ${ }^{44}$ These authorities, however, receive few reports, ${ }^{45}$ and their disciphnary power therefore cannot be a substantial deterrent. License revocation proceedings contribute little to our understandimg of such activities because, as in other settings, the therapists ahnost invariably deny alleged derelictions rather than try to justify them. ${ }^{46}$

42. See note 32 supra.

There are indications that McCartney's expulsion was imposed more to protect the image of the profession and the organization than to punish a breach of ethics. West, supra note 20, at 22829. The ethics committee chair wrote that "[t]here comes a point . . . at which the offender so outrages social sensibilities that the peer group inust act to protect its own integrity ...." Branch, Men of Good Conscience, Psychiatric News, Apr. 1969, at 2. A popular writer found it significant that none of McCartney's patients complained, and stated that the therapist "seems to have been a victim of the static moral climate that preceded America's cultural revolution." Gaines, Sex on the Couch: Analysts and Their Patients, Cosmopolitan, Sept. 1972, at 152, 166.

So great is the apparent reluctance of the profession even to cousider the possible benefits of therapist-patient sexual activity that a psychologist who proferred, at a meeting of a state psychological association, not a confession, but merely a suggestion that the activity ought to be "researched and discussed in the scholarly councils of psychology," found himself the subject of an expulsion petition circulated by his colleagues. M. SHEPARD, supra note 5, at 2 . Another prominent and respected psychiatrist had difficulty getting a paper on the topic placed in journals of organizations in which he had "not inconsiderable influence." Dahlberg, supra note 21, at 107. These reactions suggest that professional organizations have actively sought to discourage public discussion of the problein.

43. See Tex. Rev. Civ. STAT. ANN. arts. $4505-4506$ (Vernon 1971). Roughly the same powers are given to the State Board of Examiners of Psychologists. TEx. Rev. Civ. Stat. ANN. art. 4512 (Vernon 1971). Similar statutes exist in other jurisdictions. E.g., Mass. ANN. LAws ch. 112, $\S \S 118-129$ (Michie/Law. Co-op 1975); N.Y. Educ. LAw $\$ \S 7600-7605$ (McKinney 1972).

44. E.g., Bernstein v. Board of Med. Examiners, 204 Cal. App. 2d 378, 22 Cal. Rptr. 419 (5th Dist. 1962); Morra v. State Bd. of Examiners of Psychologists, 212 Kan. 103, 510 P.2d 614 (1973); Clark v. Michigan State Bd. of Registration in Medicine, 367 Mich. 343, 116 N.W.2d 797 (1962); Jacobi v. Texas State Bd. of Med. Examiners, 308 S.W.2d 261 (Tex. Civ. App. 1958).

45. See 1 D. Hogan, The Regulation of Psychotherapists 260 (1979).

46. The sole attempt at a therapeutic justification that $I$ have discovered appeared in an opening statement for a psychologist in a license-rescission proceedimg im which he was charged with making "advances to a feunale patient which ended in sexual intercourse." Cooper v. State Bd. of Med. Examimers, D-1329 (Cal. Jan. 24, 1972), before the Psychology Examinimg Comm., Decision Dec. 15, 1972, discussed in Note, Standard of Care in Administering Nontraditional Psychotherapy, 7 U.C.D.L. REv. 56, 65-66 (1974). The committee rejected the argument and revoked 


\section{Criminal Prosecutions}

A number of psychotherapists have suggested that therapist-patient intercourse should be treated as rape. ${ }^{47}$ In most jurisdictions, however, prosecution under sexual offense laws would not be successful. ${ }^{48}$ Many rape statutes apply only if the act is committed with force and against the will of the victim, ${ }^{49}$ and of those that require no more than absence of consent, ${ }^{50}$ only a few offer a chance for successful prosecutions. ${ }^{51}$

the psychologist's license. See also Martinez v. Texas State Bd. of Med. Examimers, 476 S.W.2d 400 (Tex. Civ. App. 1972) (claim of patient consent rejected).

In proceedings before the New York Board of Regents, psychiatrist Martin Shepard denied allegations that he engaged in "various types of heterosexual and homosexual intercourse with patients." Chapman, Memoirs Cost Psychiatrist His License, Legal Aspects of Med. Prac., Oct. 1978, at 40 . He contended that the participants in the activity were "friends, associates, and neighbors," id. Nonetheless, his license was revoked.

47. Masters \& Johnson, supra note 16 , at 553, make the strongest statement on the point. For other discussions of the issue, see Davidson, supra note 5, at 48; Grunebaum, Nadleson, \& Macht, supra note 33, at 12; Redhch, supra note 8, at 149.

48. Although physicians and psychotherapists have been convicted of sexual offenses against patients, generally these cases involved especially offensive facts, such as patients who were quite young, e.g., People v. Bernstem, 171 Cal. App. 2d 279, 340 P.2d 299 (4th Dist. 1959) (psychiatrist convicted of statutory rape for having sexual intercourse with a 16-year-old girl sent to him to be treated for promiscuity); State v. Martim, in J. Goldstern, A. DERShowITZ, \& R. SCHWARTZ, supra note 5, at 3-31 (actual case with fictitious naines), or who were drugged by the therapist, e.g., Ballard v. Superior Court, 64 Cal. 2d 159, 410 P.2d 838, 49 Cal. Rptr. 302 (1966); People v. Middleton, 38 11l. App. 3d 984, 350 N.E.2d 223 (1976). Several states have criminal statutes providing that any person laving sexual intercourse with another who is under the influence of a drug is guilty of rape. See, e.g., Miss. CodE ANN. § 97-3-65 (1972); N.J. STAT. ANN. § 2A:138-1 (West 1969). Other states provide that a man who has carnal knowledge of a woman after giving her a drug that prevents her effective resistance is guilty of an offense distinct from, but punishable as, rape. See, e.g., ALA. CODE tit. 13, § 13-1-132 (1975); TENN. CODE ANN. § 39-3704 (1975).

49. See, e.g., GA. CODE ANN. § 26-2001 (1977); R.I. GEN. LAws § 11-37-1 (1956).

50. See, e.g., Kan. Stat. ANN. §21-3502 (Weeks 1974); OKLA. Stat. ANn. tit. 21, § 1111 (West 1951). Many states have adopted the Model Penal Code and more may be expected to do so. It provides that the actor is guilty of rape when there is no legally effective consent due to the fact that "he knows that she suffers froin a mental disease or defect which renders her incapable of appraising the nature of her conduct." MODEL PENAL CODE § 213.1(2)(b) (1962).

51. Under Texas law, for example, consent is absent if the actor "knows that as a result of mental disease or defect, [the victim] is at the time of the intercourse incapable either of appraising the nature of the act or of resisting it . . . "TEX. PENAL CODE ANN. tit. 5, § 21.02(b)(4) (Veruon 1977). Although the situations under consideration here involve patients who were competent at the beginning of therapy, this provision would apply if the transference could be seen as a "mental disease or defect" that renders the complaining patient incapable of appraising the act or resisting it. See Stone, supra note 40, at 1139.

Ohio makes it a felony of sexual battery for a person to engage in sexual conduct with a person to whom lie is not married, if, inter alia,

(1) [t]he offender knowingly coerces the other person to submit by means that would

prevent resistance in a person of ordinary resolution.

(2) [t]he offender knows that the other person's ability to appraise the nature of or con-

trol his or her own conduct is substantially impaired.

Ohio Rev. Code ANN. $\$ 2907.03$ (Page 1975). Dr. Alan Stone suggested that "this statute might be applicable if prosecutors and juries believed that transference creates a coercive relationship." Stone, supra note 40 , at 1139 . 
Even under the most inclusive statutes, prosecutions seem unlikely. This is due in part, of course, to the natural reluctance of patients to report to authorities. But a more significant barrier to prosecution may be raised by the same credibility problem and hint of "victim precipitation" that tend to prevent prosecutions and aid the defense in ordinary rape cases. ${ }^{52}$ Similar obstacles probably would confront victims bringing such criminal charges as false pretenses or seduction. ${ }^{53}$ Laws against fornication, where they exist, ${ }^{54}$ also are unlikely to be enforced.

Any cases that are prosecuted will involve the worst kinds of behavior, and as in other forums, therapists typically will deny rather than attempt to justify the alleged acts. ${ }^{55}$ Thus, crimmal law, im harinony with the other social control devices, neither acts as a deterrent nor contributes to our understanding of the problem.

\section{Civil Actions}

Civil actions niay be brought against a psychotherapist who has been sexually intimate with a patient under two theories: interference with family relations or professional neghigence.

\section{Interference with Family Relations.}

Actions of this type, which he not for the patient herself, but for her husband, are decidedly anachromistic and have been abolished im

The two states with statutes most favorable to an aggrieved patient are New Hampshire and Michigan. In the former, it is a felony to perform "sexual penetration . . . [w] hen the actor engages in the medical treatment or examination of the victim im a manner or for purposes which are not medically recognized as ethical or acceptable." N.H. REv. STAT. ANN. § 632-A:2VII (Supp. 1977). Michigan has a similar provision, Mich. CoMp. LAws ANN. $\S 750.520(\mathrm{~b})(\mathrm{f})$ (1977), and also treats as a felony any representation by a therapist to a patient that sex with anyone except her husband "is, or will be, necessary or beneficial to her health . . . ." MicH. CoMP. LAws ANN. $\S$ 750.90 (1978).

52. See Gobert, Victim Precipitation, 77 Colum. L. Rev. $511,537-40$ (1977).

53. See, e.g., GA. CoDE ANN. § 26-2005 (1977); R.I. GEN. LAws § 11-37-4 (1956). Laws of this type generally provide that the victim be unmarried and many require that she be chaste.

54. Laws criminalizing sexual intercourse between unmarried persons remain in only a few jurisdictions. See, e.g., GA. CODE ANN. § 26-2010 (1977); IDAHO CODE § 18-6604 (1972). New Jersey's formication statute was recently held unconstitutional. State v. Saunders, 75 N.J. 200, 381 A.2d 333 (1977). But cf. Doe v. Commonwealth's Attorney, 403 F. Supp. 1199 (E.D. Va. 1975), affd mem., 425 U.S. 901 (1976) (summarily affirming constitutionality of Virginia's sodomy statute).

55. But cf. State v. Martin im J. GoldsteIN, A. DeRshowitz, \& R. Schwartz, supra note 5, at 3-3I (after physician pleaded nolo contendere to a charge of indecent assault, based upon his having had homosexual relations witl young boys who were either patients or siblings of patients at his home for disturbed boys, his counsel argued that the sexual relations were for therapy and that his inotive should be considered; the court concluded, however, that the defendant was the aggressor and that the sexual activity was not for therapeutic purposes). 
most jurisdictions. ${ }^{56}$ Where these actions still he, the most appropriate is criminal conversation, which sounds in trespass. ${ }^{57}$ A plaintiff need only show that the defendant had sexual imtercourse with his wife during the marriage and without his consent..$^{58}$ Because this action is so easy to establish, it inay serve as the basis for a significant number of unreported plaintiff's judgments and out-of-court settlements where it exists. But simce consent of the wife is not a defense, there is no chance that a defendant would try to justify his alleged sexual relations. Thus, criminal conversation actions are not a vehicle for uncovering information about therapist-patient sexual activity.

\section{Professional Negligence}

The cause of action patients most commonly pursue is professional negligence. ${ }^{59}$ This action, like the other social controls discussed above, does not effectively deter therapist violations because, again, few patients sue. Patients' reluctance to make claims is caused not only by the factors that make reporting to professional organzations and $\mathrm{h}$ censing authorities unattractive, but also by the difficulty of proving dainages and causation.

Because of these disincentives, negligence claims are brought only in those cases that involve facts so extreme as to enable the plaimtiff easily to prove causation and damages. ${ }^{60}$ These cases, therefore, do not provide a representative sample from which to draw inferences about therapist-patient sexual relations. Moreover, nrany are settled out of

56. Fagden v. Lenker, $469 \mathrm{~Pa} .272,365$ A.2d 147 (1976) (judicial abolition of criminal conversation action); W. Prosser, HANDBOOK OF THE LAW OF TORTS 887 (4tli ed. 1971). Alienation of affections lias been abolislied by legislation in 17 jurisdictions. J. AREEN, FAMILY LAw 174 (1978). For a negative view of this trend, see Note, The Case for Retention of Causes of Action for Intentional Interference With the Marital Relationship, 48 Notre DaME LAw. 426 (1972). “Antiheart balm" statutes, if broadly construed, could bar actions based on therapist-patient sexual intinacy. See Nicholson v. Han, 12 Micl. App. 35, 162 N.W.2d 313 (1968); Fagden v. Lenker, $469 \mathrm{~Pa} .272,365$ A.2d 147 (1976). Such a defense was rejected, however, in Roy v. Hartogs, 85 Misc. 2d 891, 381 N.Y.S.2d 587 (App. Term 1976).

57. See W. Prosser, supra note 56, at 874.

58. Id. at 876. The plaintiff need not show that he was deprived of any of his wife's services in order to recover damages. $I d$.

A related cause of action for ahenation of affections would lie in some jurisdictions. It is more difficult to establish than criminal conversation as it requires plaintiff to prove that the defendant, "acting for the purpose of affecting the marital relation," deprived him of his wife's affection. Privilege is a defense. Id. at 875 .

59. See Roy v. Hartogs, 81 Misc. 2d 350, 366 N.Y.S.2d 297 (Civ. Ct. N.Y. 1975), affd, 85 Misc. 2d 891, 381 N.Y.S.2d 587 (App. Term 1976); Landau v. Werner, 105 Sol. J. 257, affd, 105 Sol. J. 1008 (C.A. 1961). As with Roy, such claims often include battery counts. Patieuts inay also bring actions for fraud and deceit. See Griffin v. Phillips, 542 S.W.2d 432, 433, 436 (Tex. Civ. App. 1976).

60. E.g., Greenberg v. McCabe, 453 F. Supp. 765 (E.D. Pa. 1978); Roy v. Hartogs, 81 Misc. 2d 350, 366 N.Y.S.2d 297 (Civ. Ct. N.Y. 1975), affd, 85 Misc. 2d 891, 381 N.Y.S.2d 587 (App. Tern 1976); Landau v. Werner, 105 Sol. J. 257, affd, 105 Sol. J. 1008 (C.A. 1961). 
court and so can provide no information at all. ${ }^{61}$

If a neghigence action does go to trial, the therapist, again, will almost inevitably deny the alleged intimacy because he caimot reasonably expect to justify it; the standards of care employed by the courts preclude acceptance of sexual relations as therapeutic treatment. For example, in medical malpractice suits that involve innovative or mappropriate treatment, some courts have stated that a practice is negligent unless "supported by a respectable minority."62 Others have held that "any variance from the accepted mode of treatinent renders the physician liable,"63 and still others allow no more than "what a reasonable and prudent doctor would have done under the circumstances."64 Plainly, sexual relations do not conform to any of these standards. The two leading cases im the area further illustrate the difficulty of justifying the alleged behavior. In Landau $\nu$. Werner, ${ }^{65}$ the court said that a psychiatrist who tries a technique that does not accord with the "ordinary and reasonable standards of those who practice in the same field of medicine" will be considered neghgent and liable for resulting mjuries unless he can justify the new technique. "Success," it said, "[i]s the best justification for unusual and unestabhshed treatment."67 And in Roy v. Hartogs, ${ }^{68}$ the defendant denied the allegations, and acknowledged that "patients should not have sex with their psychiatrists,"69 thereby helping the patient establish the standard.

Defense of sexual imtimacy between therapist and patient is made even less attractive by the fact that an admission would almost cer-

61. Stone, supra note 40 , at 1140.

62. See Hood v. Phillips, 554 S.W.2d 160, 164 (Tex. 1977), and cases cited therein.

63. See id. at 165 and cases cited therein.

64. See id. and cases cited therein.

65. 105 Sol. J. 257, affd, 105 Sol. J. 1008 (C.A. 1961).

66. Id. at 1008 .

In Landau, a male psychiatrist treated a middle aged woman for anxiety for about six months, by which time she had improved substantially, but had fallen in love with him and wanted to end treatunent. Fearing that an abrupt termination of their relationship might bring about a relapse, he began seeing the woinan socially. Then, as part of his plan, he gradually ended the social contacts (it was not claimed specifically that they were sexual). This led the former patient to atteinpt suicide, and the psychiatrist was moved to resume treatment. Having no success, he broke off the entire relationship. This caused the woman's inental condition to deteriorate to such an extent that she was incapable of working, and, on the basis of expert testinony, the psychiatrist was found to have committed professional negligence.

67. Id.

68. 81 Misc. 2d 350, 366 N.Y.S.2d 297 (Civ. Ct. N.Y. 1975), affd, 85 Misc. 2d 891, 381 N.Y.S.2d 587 (App. Term 1976).

69. L. FREEMAN \& J. RoY, BETRAYAL 226 (paperback ed. 1977).

In Roy, the plaintiff won a judgment on a inalpractice count for aggravation of her preexisting inental condition, which caused her to seek hospitalization. She alleged that the defendant psychiatrist had sexual intercourse with her over a thirteen inonth period as part of his prescribed course of therapy. 
tainly cost a therapist any legal defense services that otherwise would be provided by his malpractice imsurance carrier. ${ }^{70}$ This fact also would discourage a therapist from seeking to excuse the sexual contact on the basis that it occurred outside of the therapeutic relationship.

\section{III}

\section{Recommended Community Policy}

I have discussed the failure of existing social control devices either to deter or to provide accurate information about the effects of therapist-patient sexual encounters. In this section, I propose a community policy that will overcome these failures.

The present need for information can best be satisfied by prospective research on the therapeutic outcomes of therapist-patient sexual activity; this, in turn, would permit a systematic analysis of the propriety of therapist-patient sexual relations. ${ }^{71}$ The research could have important implications for controlling such behavior, as well as for exploring new therapeutic possibilities. Suppose, for instance, that the research suggested that only patients with condition $X$ tend to benefit from sexual relations with their psychotherapists. Professional organizations might modify their blanket ethical proscriptions accordingly. Sexual therapy might become a recognized treatınent for patients with condition $X$ and, perhaps more important, therapists would be put on notice that although sexual relations might be indicated for condition $X$, they are unethical for any other condition. Such a tailored imjunction, based on enipirical evidence rather than conjecture, is likely to be niore persuasive than the current absolute one. If on the other hand, the research failed to suggest any condition for which sexual relations might be helpful, professional organizations would have a better justification for maintenance of the absolute proscription, and therapists would have a clearer reason for complying with it. Moreover, to the extent that the research and its results become known to the public,

70. The malpractice insurance carrier for the American Psychological Association will not pay damages assessed against an insured psychologist based upon sexual contact with a patient. It will, however, pay his legal defense costs if he denies the allegations. Asher, Confusion Reigns in APA Malpractice Plan, APA Monitor, Mar. 1976, at 1, col. 1; Letter fron1 Mary D. Logan, Administrative and Projects Assistant, Office of Professional Affairs, American Psychological Association, to Dr. J. Ray Hays (Apr. 13, 1978) (on file with California Law Review). Not all imsurance carriers would be willing to defend a psychotherapist even if he denied having had the alleged relations. The defendant's malpractice carrier in Roy v. Hartogs, 81 Misc. 2d 350, 366 N.Y.S.2d 297 (Civ. Ct. N.Y. 1975), affd, 85 Misc. 2d 891, 381 N.Y.S.2d 587 (App. Term 1976), refused to defend. Hartogs v. Employers Mut. Ins. Co. of Wis., 89 Misc. 2d 468, 391 N.Y.S.2d 962 (Sup. Ct. 1977).

71. For an idea of what should be considered in such analysis, see ETHICAL Issues, supra note 24 , at 161 . 
patients' susceptibility to sexual advances from their therapists should be dininished. Thus, such research could produce significant benefits.

On the other hand, if conducted improperly or imprudently, the research itself unay threaten certain important interests: the digmity and autonouny of the patient-subject, the reputation of the professions, and society's interest in the trustworthiness of its professions. In order to inake prospective research possible while protecting these interests, society should, I submit, consider therapist-patient sexual relations justifiable if and only if performed for the purpose of producing sigmificant data, and in a manner that will present minimal threats to other values. I recommend, in other words, that community policy should be that sexual relations between psychotherapist and patient are justifiable only if performed for research purposes under conditions that protect important interests of the patient, the therapist, the psychotherapeutic professions, and society. In the next section I shall discuss the implementation of this policy.

IV

A Means of Effectuating Recommended Policy: JUSTIFICATION THROUGH REVIEW AND APPROVAL

It is well-established that control of research on human subjects cannot be left simply to the authority of the subjects and researchers witlout doing violence to important values. ${ }^{72}$ This would be especially true of research on the therapeutic value of therapist-patient sexual relations. Not only is the therapist-investigator's potential conflict of interest inore emotionally charged in this type of investigation, but the patient-subject may be particularly vulnerable.

General policies governing research on lruman subjects are already well-established. These policies, set out in the Nuremberg $\mathrm{Code}^{73}$ and the Declaration of Helsinki, ${ }^{74}$ make the propriety of such researcl dependent upon three basic conditions: that the possible benefits outweigh the risks, ${ }^{75}$ that informed consent be obtained, ${ }^{76}$ and that the rights and welfare of the subject be protected. ${ }^{77}$ Department of Health, Education, and Welfare regulations governing HEW-funded researcli incorporate these requirements and add another: the research

72. See notes 73-74, 78 and accompanying text infra.

73. U.S. v. Brandt, 2 Trials of War Criminals Before the Nuremberg Military Tribunals (The Medical Case) 181 (Military Tribunal 1 1947).

74. World Medical Association, Declaration of Helsinki, 271 NEw ENG. J. MED. 473 (1964).

75. NuREMBERG CODE, Principle 6; Declaration of Helsinki, supra note 74, § I, Principle 4.

76. Id. Principle 1, \& III, 3a, 3b, 3c.

77. Id. Principle 9, § III, 4a, 4b. 
must be approved by an "Institutional Review Board"78 (IRB) composed of "persons with varymg backgrounds,"79 and charged with determining that the other requirements have been met. ${ }^{80}$

This review system is the most appropriate means of protectimg the interests threatened by sex-as-therapy research. It requires that the boards be so constituted as to be able to judge the acceptability of research protocols "in terms of institutional commitments and regulations, applicable law, standards of professional conduct and practice, and community attitudes."81 Moreover, through federal agencies and HEW-supported institutions it already governs nearly all biomedical and behavioral research in this country. ${ }^{82}$ And there is an imcipient movement in professional organizations to have such review procedures apply to research outside of federal agencies or HEW-funded institutions. ${ }^{83}$

78. HEW Regulations on the Protection of Human Subjects, 45 C.F.R. $\$ 46.102-.211$ (1977).

79. Id. $\$ 46.106(\mathrm{~b})(1)$.

80. $I d$.

81. Id.

The National Commission for the Protection of Human Subjects of Biomedical and Behavioral Research [hereinafter referred to as the Commission] has recently recommended efforts to improve and increase the coverage of this regulatory scheme. NATIONAL COMMISSION FOR THE Protection of Human Subjects, Report and Recommendation: Institutional Review BOARDS (1978) [hereinafter referred to as IRB REPORT].

82. More than three-fifths of all "medical and health-related" research and development is funded by the U.S. Government, U.S. Dep't of Health, Education \& Welfare, Secretary's TASK ForCe on the CoMpensation of INJURed ReSEARCh SUbjects III-l (1977), and virtually all federal agencies with policies for the protection of human subjects currently adopt HEW standards and procedures to a sibstantial degree. IRB REPORT, supra note 81, at 4. See FDA Proposed Standards for Institutional Review Boards for Clinical Investigations, 43 Fed. Reg. 35,186 (Aug. 8, 1978). It has been recommended recently that HEW be designated the "single authority for issuing regulations on protection of human subjects." IRB REPORT, supra note 81, at 3 .

Much of the nonfederally-funded research is also effectively covered by these procedures because it is carried out through institutions that undertake some HEW-funded research, and HEW requires that such institutions apply this review system to all research. Robertson, The Law of Institutional Review Boards, 26 U.C.L.A. L. Rev. 484, 499 (1979).

83. A gentle move in this direction was taken by the Aunerican Psychological Association when it established procedures for obtaining informed consent and minimizing dangers to researcli participants. Am. Psychological Ass'N, Ethical Principles in the Conduct of ReSearch Involving Human Participants 1-2 (1973). Although the APA Principles do not suggest that research be subuitted to an IRB, they do entreat an investigator who thinks his study may violate an ethical principle to "seek ethical advice [from an ad hoc or continuing peer group] and to observe more stringent safeguards to protect the rights of the human research participants." Id. at 1.

A stronger, though still ambiguous, position is taken in the Code of Ethics of the American Association of Marriage and Family Counselors: "The counselor is obligated to protect the welfare of his or her research subjects. The conditions of the Hunan Subjects Experimentation shall prevail, as specified by the HEW guidelines." American Ass'N MARr. \& Fam. Counselors, Code of PRofessional ETHics § III, 1.

The inost direct statement comes from recently developed ethics guidelines. These recommend "that sex research protocols be submitted to an institutional review board for evaluation of ethical propriety. Investigators not affiliated with an institution that has an accredited review 
Therefore, my recommendation for effectuating the policy suggested above is that therapist-patient sexual relations should be regarded by professional organizations as ethically justifiable and by courts in civil actions as legally justifiable, but only if performed pursuant to a research protocol reviewed and approved under a system similar to that required by HEW regulations. ${ }^{84}$ The remainder of this section describes the most important obstacles that professional organizations, courts, and investigators themselves may face in accepting and impleinenting this recommendation.

\section{A. Professional Organizations}

It may be argued that professional organizations' present ethical bans on therapist-patient sexual contact deal only with the therapeutic relationship, and do not preclude prospective research. ${ }^{85}$ But because of the harsh disciplinary actions imposed by such organizations in the past, ${ }^{86}$ this argument itself probably would not sufficiently encourage investigators. Rather, if prospective research is to be carried out openly, professional organizations must specifically except it from the absolute prohibitions.

At first glance, it would seem that impleinentation of my recoinmendation should pose no difficulties for such organizations. After all, the ethical bans on therapist-patient sexual activity are ostensibly based on fears that the therapist will lose his objectivity and exploit the patient. ${ }^{87}$ A properly approved research protocol would enforce objectivity and protect the interests of the patient, thus diluting those fears and rendering absolute prohibitions inappropriate. ${ }^{88}$ If these fears are the

board are encouraged to arrange voluntarily to have their protocols reviewed and to accept the judgment of the reviewing body." Reproductive Biology Research Foundation, Ethics Guidelines for Sex Therapists, Sex Counselors and Sex Researchers § V-10 (Mar. 1978 Final Revision) (to be published in 1979).

84. Cf. National Commission for the Protection of Human Subjects of BiomediCal and Behavioral Research, The Belmont Report: Ethical Principles and Guidelines for the Protection of Human Subjects of BIomedical and Behavioral Researcil 3-4 (1978) [hereinafter referred to as THE BELMONT REPORT].

85. See note 8 supra.

86. See note 32 supra.

87. For example, an annotation to $\$ 1$ of the Code of Ethics of the American Medical Association, along with the section itself, stresses the importance of trust in the therapist-patient relationship. The annotation emphasizes avoidance of exploitation of that trust and notes that "the necessary imtensity of the therapeutic relationships may tend to activate sexual and other necds and fantasies on the part of both patient and therapist, while weakening the objectivity neccssary for control." Am. Psychiatric Ass'n, Principles of Medical Ethics with Annotations Especially Applicable to Psychiatry, supra note 8, at 1061 .

88. Cf. the opinion of the Board of Governors of the Oregon State Bar in which the question whether it is "unethical conduct for an attorney to be sexually involved with a client while representing her in a divorce action" was answered "Yes, qualified." The Board wrote: "In the class of cases where there are no children and an amicable settlement, or a default proceeding, it does not 
only reason for the present policy, then research pursuant to such a protocol should be permitted.

Unfortunately, the matter is not so simple. There are additional reasons for the maintenance of the proscriptions, and some of these may not be obviated so easily by iny recommendation. Indeed, my proposal itself may present problems that will interfere with its adoption by professional organizations.

The inost noticeable difficulty is the honest behef among the great inajority of psychotherapists that sexual relations with patients are nearly always harmful and never helpful. ${ }^{89}$ They think that research could only confirm what they consider already to be established. More important, they, and probably even many who beheve that research could be beneficial, fear that some therapists, either consciously or unconsciously, will misinterpret any weakening of the absolute prohibitions and turn it into an excuse to become sexually imvolved.

In addition, even limited approval of sexual contact between therapist and patient under a controlled research program may be damaging to the image of the professional psychotherapist. It may suggest to soine that the "fifth profession" $"$ has taken the first step on a road that leads to debauchery. The consequent loss of pubhic trust may, in the view of soine psychotherapists, cost the profession some autonomy ${ }^{91}$ as well as some patients.

Finally, research on any innovative therapy compels close examination of accepted practices. ${ }^{92}$ The efficacy of established techniques must serve as a control against which to measure that of the innovations. ${ }^{93}$ This scrutiny may be uncomfortable for the profession because it could reveal the disturbing fact that there is hittle or no evidence that the accepted psychotherapies are effective. ${ }^{94}$

Even if these obstacles are overcome and my recommendation is adopted by the professional organizations, the way would only partly be cleared for prospective research. The threat of hicense revocation would cease to be even potentially troublesome because of the extent to

appear that such conduct would necessarily affect the client's interest or the attorney's judgment and would not, per se, be unethical." ORegon State Bar CoMmittee on LEgal Ethics, Opinion No. 429 (May 1979).

89. Holroyd \& Brodsky, supra note 18.

90. Butler \& Zelen, supra note 28, at 139.

91. See E. Freidson, Professional Dominance 122 (1970).

92. See D. Malan, Toward the Validation of Dynamic Psychotherapy 5 (1976).

93. Goldiamond, Protection of Human Subjects and Patients: A Social Contingency Analysis of Distinctions Between Research and Practice, and its Implications, 4 BEHAVIORISM 1, 3 (1976).

94. See S. Rachman, The EfFects of Psychotherapy 162 (1971); Bergin, Psychotherapy Can Be Dangerous, Psychology Today, Nov. 1975, at 96; Conolly, Psychotherapy: Some Research Findings, 23 Bull. Sinai Hospital of Detroit 173 (1975). But see 1 D. Hogan, supra note 45 , at 24 . 
which the standards used in such proceedings are derived from professional norms of conduct. Similarly, nost of the few criminal statutes that might otherwise be applicable to therapist-patient sexual activity would become inapposite if the approved research protocol were observed. The professional negligence action, however, would reinain a threat to therapists, and im order to accommodate the public policy I have recommended-to facilitate research under carefully circumscribed conditions-the courts will have to address some of the special problems this action raises.

\section{B. Courts and the Negligence Action}

There are two distinct theories under which a plaintiff may bring suit for professional negligence. She may allege (1) that the decision to use sexual relations as a therapeutic device or the unanner in which the relations were pursued constituted a breach of the therapist's duty of care, and hence was negligent; or she may allege (2) that even if the defendant was not negligent in the above respects, he was negligent in failing to obtam informed consent. ${ }^{95}$ In order to effectuate iny recommended community policy, the courts must annend their approach to both of these causes of action. In addition, they inay have to consider, in an appropriate case, the circuunstances under which an affirmative defense based on the plamtiff's consent should be recogmized in response to the first type of suit.

\section{Negligence in Choosing or Using the Technique.}

Courts have not yet had occasion to designate the standard of care for therapeutic research. ${ }^{96}$ The standards of care they have adopted for innovative or experimental therapies are based upon the customs or

95. In some jurisdictions, this cause of action would be characterized as battery. See note 101 infra.

96. The National Commission for the Protection of Human Subjects of Biomedical and Behavioral Research has devoted some attention to the boundaries between research and experimental practices:

When a clinician attempts a major departure from standard or accepted practice, the innovation does not, in and of itself, constitute research. Simply because a procedure is "experimental," i.e., new, interesting, or different, that fact does not automatically place it in the category of research. Radically new procedures of this description should, however, be made the object of formal research at an early stage in order to determine whether they are safe and effective. Thus, it should be the responsibility of medical practice committees (and analogous committees of behavioral practice) to insist that a inajor innovation be tried as a part of a formal research project.

THE BeLMONT RePORT, supra note 84, at 2-4.

For further discussion of this issue, see London \& Klerman, Boundaries Between Research and Therapy, Especially in Mental Health, in THE BELMONT REPORT, supra note 84, at 15; Robertson, Legal Implications of Boundaries Between Biomedical and Behavioral Research Involving Human Subjects and the Accepted or Routine Practices of Medicine, in THE BELMONT REPORT, supra note 84 , at 16; Goldiamond, supra note 93 , at 1. 
practices of physicians or psychotherapists, ${ }^{97}$ and, therefore, cannot serve easily to justify therapist-patient sexual relations even if such activity takes place pursuant to a properly reviewed and approved research protocol.

In order to carry out the community pohicy I have recommendedto facilitate research, but only under prescribed conditions-courts should rule, when the case arises, that the appropriate standard of care is not that of the practitioner, but that of the reasonable therapist-investigator. Thus, when the defendant is shown to have engaged with a patient in sexual relations that were not pursuant to a properly reviewed and approved research protocol, the court should either rule that the defendant was negligent as a inatter of law or permit the jury to find negligence, which, of course, it would be likely to do.

On the other hand, a therapist who has obtained IRB approval should not be exonerated automatically; he should merely have a chance to show that he coinplied with the standard of care proposed above. If the relevant professional organization has followed my recommendation and indicated that, if properly reviewed and approved, therapist-patient sexual activity is ethically justifiable, the defendant could introduce that fact as evidence of how a reasonable therapistinvestigator would behave. Or, if the professional organization has not taken such action, the therapist probably could muster expert witnesses on his behalf froin ainong ineinbers of the IRB. The plaintiff might, however, still prove negligence by showing that the defendant did not adequately coinply with the protocol, that the IRB's risk-benefit analysis was flawed, ${ }^{98}$ or that the IRB otherwise acted without due care. ${ }^{99}$

\section{Informed Consent}

Even if the defendant is not negligent under the reasonable therapist-investigator standard in deciding upon or carrying out sex-as-therapy research, the patient may have a cause of action in negligence for failure to obtain informed consent. ${ }^{100}$ She would have to show, inter

97. See text accompanying notes 63-69 supra.

98. See Robertson, supra note 96, at 16-18.

Under my proposal, the court would view the risk-benefit ratio as an IRB would, and not solely from the perspective of the patient-subject.

99. Id.

For a discussion of the potential liability of IRB members for their own negligence, see Robertson, The Law of Institutional Review Boards, 26 U.C.L.A. L. REv. 484, 532-33 (1979).

100. If a pliysician fails to disclose the nature of a procedure or goes beyond the bounds of a procedure he did describe, the patient's action for failure to obtain informed consent will sound in battery. But where the nature of the procedure is disclosed, yet an undisclosed inherent risk materializes, courts liave divided on whether the action sliould be for battery or negligeuce. The trend is very strongly toward negligence. Cobbs v. Grant, 8 Cal. 3d 229, 240-41, 502 P.2d 1, 7-8, 104 Cal. Rptr. 505, 51 1-12 (1972); Katz, Informed Consent-A Fairy Tale? Law's Vision, 39 U. PirT. L. 
alia, that the defendant failed to meet his duty of care to disclose enough information to permit the patient to inake an intelligent decision whether to undergo the treatinent. ${ }^{101}$

Some innovations will be needed to apply the informed consent doctrine in a case involving sex-as-therapy research. Although many inforined consent cases involving accepted or experimental therapy have been hitigated, ${ }^{102}$ courts have not had occasion to consider the obligation to obtam informed consent in a research setting. It seems clear, however-not only under my proposal, but also under general principles-that the backbone of this obligation should be the provision of the HEW regulations that define informed consent as "the knowing consent of an individual or his legally authorized representative, so situated as to be able to exercise free power of choice without any undue inducement or any element of force, fraud, deceit, duress, or any form of constraint or coercion," 103 and specifies "the basic elements of information necessary." 104

This regulation provides significant guidance. The requirenent that consent be knowing and voluntary suggests, for instance, that consent inust be obtained before the development of a transference. But this definition does not supply the courts with a standard for ineasuring compliance with it. What should that standard be?

REv. 137, 165 (1978). Accordingly, battery will not be discussed in this Article. It is interesting to note, however, that one of the principal reasons for the trend from battery to negligence-the presumption that the physician is acting from the best of intentions, see Riskin, Informed Consent: Looking for the Action, 1975 U. ILL. L.F. 580, 593-95-is far less vahid in the situation under discussion than in the nornal medical malpractice case.

101. In addition to proving that the defendant breached his duty of care, the plaintiff must show that she was injured as a result of an undisclosed danger, and that a causal relationship existed between the failure to disclose and the injury, i.e, that had the disclosure been made, she, or in soine jurisdictions, a reasonable person in her position, would have declined the procedure. See Canterbury v. Spence, 464 F.2d 772 (D.C. Cir.), cert. denied, 409 U.S. 518 (1972).

102. See notes $105-10$ and accompanying text infra.

103. 45 C.F.R. § 46.103(c) (1977).

104. These include:

(1) A fair explanation of the procedures to be followed, and their purposes, including identification of any procedures which are experimental;

(2) A description of any attendant discomforts and risks reasonably to be expected;

(3) A description of any benefits reasonably to be expected;

(4) A disclosure of any appropriate alternative procedures that might be advantageous for the subject;

(5) An offer to answer any inquiries concerning the procedures;

(6) An instruction that the person is free to withdraw his consent and to discontinue participation in the project or activity at any time without prejudice to the subject; and (7) With respect to biomedical or behavioral research which inay result in physical injury, an explanation as to whether compensation and medical treatment is available if physical injury oceurs, and if so, what it consists of or where further information may be obtained. ...

45 C.F.R. $\$ 46.103$ (c)(1) to (c)(7) (1977), as amended by 43 Fed. Reg. 51,559 (Nov. 3, 1978).

Violation of regulations inay be used as evidence of neghigence. Claypool v. Mohawk Motor, Inc., 155 Ohio St. 8, 11, 97 N.E.2d 32, 34 (1951). 
In informed consent cases involving conventional or experimental treatment, courts are divided as to the standard used to measure fulfillment of the duty to disclose. The majority use a professional standard based upon the practices of a reasonable practitioner. ${ }^{105}$ A minority use a standard "set by law" and based upon what a patient would want to know. ${ }^{106}$ Most of these minority jurisdictions use an objective standard, looking to the reasonable patient. ${ }^{107}$ Some use a subjective standard that focuses on what the individual patient-plaintiff would find material. ${ }^{108}$ In cases involving experimental treatment, courts using each standard have indicated that the experimental nature of the procedure must be disclosed. ${ }^{109}$ But courts have not made any further distinction between the disclosures required for routine and innovative treatments; 110 and they have had no occasion to rule upon the duty of disclosure in research.

Given that an objective of the HEW regulatory scheme is to transfer power from the researcher to the subject and the IRB, it is obviously counterproductive for a professional standard to govern disclosure. ${ }^{111}$ Disclosure should be ineasured by the need of the subject. The National Commission for the Protection of Human Subjects of Biomedical and Behavioral Research recently suggested that the appropriate standard to measure comphance with the duty to disclose is an objective one, what a "reasonable volunteer" would want to know. ${ }^{112}$ Although this may be adequate for some kinds of research, it seems a poor choice

105. See Riskin, supra note 100 , at $585-86$.

106. Id at 586-87.

107. Id. at 587.

108. Id at $587-91$.

109. Clements v. Regents of Univ. of Cal., 8 Cal. App. 3d 1, 87 Cal. Rptr. 108 (2d Dist. 1970) (professional standard); Fiorentino v. Wenger, 19 N.Y.2d 407, 227 N.E.2d 296, 280 N.Y.S.2d 373 (1967) (societal standard). It is interesting to note that these two states have changed standards since the above cited decisions appeared. See Cobbs v. Grant, 8 Cal. 3d at 245, 502 P.2d at 11, 104 Cal. Rptr. at 515, which imposes the societal standard; N.Y. PUB. HEALTH LAW $\S 2805-d(3)$ (McKinney 1977), which imposes a professional standard. Since 1975, several states have enacted statutes dealing with informed consent, but none have dealt with experimentation or research. See G. AnNas, L. Glantz, \& B. Katz, InFormed Consent to Human Experimentation: THE SuBJECT's DILEMMA 38-42 (1977) [hereinafter cited as ANNAS]. A very recently enacted California statute makes willful failure to obtain informed consent to biomedical research a misdeineanor and provides civil damages for willful or negligent failure to obtam such consent. Informed consent is described in terms similar to those found in HEW regulations, supra note 103. See Protection of Human Subjects in Medical Experimentation Act, Ch. No. 360, $\$ \$ 24170-$ 24179.5, 1978 Cal. Legis. Serv. 997 (West).

110. See Karp v. Cooley, 493 F.2d 408, 423-24 (5th Cir.), cert. denied, 419 U.S. 845 (1974).

111. Cf. ANNAS, supra note 109, at 44: "The general conclusion is that more detailed disclosures and no therapeutic privileges should be the rule in the experimental setting." (emphasis in the original).

112. ThE BeLmont Report, supra note 84, at 11. This is consonant with the reasonable patient standard adopted in Canterbury v. Spence, 464 F.2d 772, 787 (D.C. Cir.), cert. denied, 409 U.S. 1064 (1972). 
for informed consent cases arising from research on therapist-patient sexual relations as therapy. A subjective standard, based upon what the subject in question would find inaterial, is preferable. ${ }^{113}$

Surely a subjective standard is inore supportive of the patient-subject's human dignity. ${ }^{114}$ Moreover, a decision to employ the subjective, patient-oriented standard of disclosure eases the difficult problein raised by the HEW requirenent of "[a] disclosure of any appropriate alternative procedures that might be advantageous for the subject." 115 Clearly, compliance with this requirement could not be achieved by reference to the "professional" standard. Though professional organizations $^{116}$ and commentators ${ }^{117}$ accept the obligation to obtain informed consent in therapy as well as research, and though most persons seeking psychotherapy know hittle about either the process ${ }^{18}$ or the significant dangers associated with it, ${ }^{119}$ psychotherapists are not in the habit of disclosing even the nature of the proposed treatment, let alone any alternatives. ${ }^{120}$

Nor would reference to an objective standard adequately protect the autonomy of many patient-subjects. The unique and highly per-

113. For arguments in favor of a subjective standard, see Capron, Informed Consent in Catastrophic Disease Research and Treatment, 123 U. PA. L. REv. 340, 408-18 (1974).

114. See Canterbury v. Spence, 464 F.2d 772, 787 (D.C. Cir.), cert. denied, 409 U.S. 1064 (1972).

115. 45 C.F.R. § 46.103(c)(4) (1977).

116. See Am. Psychological ass'n, Ethical Principles in the Conduct of Research Involving Human Participants, supra note 83, Principle 3; AM. Psychological Ass'N, EthICAl Standard of Psychologists, supra note 8, Principles 3 \& 4; AM. Psychological Ass'N, Standards for Providers of Psychological Services, Std. 2.3.2 (1977).

117. See Sadoff, Informed Consent, Confidentiality and Privilege in Psychiatry: Practical Applications, 2 Bull. AM. ACAD. PsychiatRy \& L. 101 (1974); Tryon, Behavior Modification and the Law, 7 PROFEsSIONAL PSYCH. 468 (1976). For a discussion of the importance of informed consent relative to the therapist's potential duty to warn third parties of the patient's dangerous proclivities, see Fleming \& Maximov, The Patient or His Victim: The Therapist's Dilemma, 62 Calif. L. REv. 1025, 1056-60 nn.159-87 (1974).

118. See C. Kadushin, Why People go to Psychiatrists 204 (1969).

119. See The Belmont Report, supra note 84, at 15; M. Gross, The Psychological SociETY 40-43, 204-07, 302-10 (1978); Bergin, supra note 94, at 96; Sherrer \& Sherrer, Professional or Legal Standards for Academic Psychologists and Counselors, 1 J.L. \& ED. 289-96 (1972). Much of the danger, however, may be associated with poor therapists. See M. Gross, supra at 40; M. Lieberman, I. YALOM, \& M. MILES, ENCOUNTER GROUPS: FirSt FACTS (1973); Bergin, supra note 94, at 96; Hogan, Encounter Groups and Human Relations Training: The Case Against Applying Traditional Forms of Statutory Regulation, 11 HARV. J. LEGIS. 659 (1974).

120. See Epstein, Informed Consent and the Dyadic Relationship, 6 J. PSYCHIATRY \& L. 359, 360 (1978); Robitscher, Informed Consent for Psychoanalysis, 6 J. PsYCHIATRY \& L. 363, 370 (1978).

This is due in part to the fact that the legal doctrine of informed consent presents little threat to the psychotherapist using an accepted psychotherapy for therapeutic purposes, see Fishalow, The Tort Liability of the Psychiatrist, 3 Bull. AM. ACAD. PsychlatRY \& L. 191, 195-97 (1975); the "therapeutic exception," see Riskin, supra note 100, along with the difficulty of proving causation and damages almost ensure that he will not incur legal hability for failing to obtain infonned consent. 
sonal nature of any condition for which a sexual relationship could appropriately be prescribed makes it important that the disclosure requirements be determined by the subject's individual needs. Moreover, the primary advantage of an objective standard - the greater ease with which it can be applied and satisfied-is not present in our situation. Because the IRB probably will require extensive peer review with respect to each subject, personalized standards for disclosure would be much more practical here than in many research settings.

I do not mean to suggest that the conventional judicial approach to informed consent, einphasizing disclosure of information, is adequate to protect the patient-subject's dignity and autonomy. ${ }^{121}$ True respect for the patient-subject's digmitary imterest in making her own choices would require at least that courts impose upon the therapist-investigator the additional duty of insurmg that the patient-subject understands. ${ }^{122}$ It would be even better for courts and juries to scrutinize the entire process of interaction between therapist-investigator and patientsubject, as has been recently proposed by Jay Katz, ${ }^{123}$ but no satisfactory ineans for doing so has yet been articulated. ${ }^{124}$

\section{Consent as a Defense.}

The action for failure to obtam informed consent is not the only way for the question of consent to come up in a trial. The defendant inay seek to raise it under the common law primciple of volenti non fit injuria - "to one who is willing, no wrong is done."125 In a neghigence action, the defendant may raise the affirmative defense of assumption of the risk, which, if accepted, has the effect of relieving the defendant

121. See Katz, supra note 100, at 139-43; Riskin, supra note 100, at 590-600.

122. Cf. ANNAS, supra note 109, at 44 (imvestigator should ascertain subject's level of comprehension); THE BELMONT REPORT, supra note 84, at 11 ("Investigators are responsible for ascertaining that the subject has comprehended the information.'); Capron, supra note 113, at 408 ("[c]oncern should focus on whether the patient-subject understood what the physician-investigator was proposing to do"). But see 39 Fed. Reg. $306-49$ (1974) (declining to adopt suggestions to amend 45 C.F.R. $§ 46.3$ (c) (1974) to include an assurance that the patient understands the disclosure, on the ground that this "goes beyond requirenents for informed consent as they have generally been articulated by courts"); Goldstem, For Harold Lasswell: Some Reflections on Human Dignity, Entrapment, Informed Consent, and the Plea Bargain, 84 Y ALE L. J. 683, 686 (1975).

123. See Katz, supra note 100 , at $142-43$.

124. Id. Jay Katz has written:

Decision-making in medicine ought to be a joint undertaking and depends inuch inore on the nature and quality of the entire give-and-take process and not on whether a particular disclosure has or has not been inade. How to translate the ingredients of this process into useful legal prescriptions which are respectful of patients' quests to inaintain and impulse to surrender autonomy as well as the physicians' unending struggle with omnipotence and impotence is a difficult task which has not yet been undertaken.

Id. at 173.

125. See W. Prosser, supra note 56, at 439-57. 
of his duty of care. ${ }^{126}$ If courts are to effectuate the community policy I lave recommended, lowever, this defense should never be recognized in lawsuits of the type under discussion.

Courts liave refused to give effect to the assumption of risk defense where to do so would violate public policy, as, for instance, where the parties were in unequal bargaining positions, ${ }^{127}$ where the manifestation of consent was not entirely free and voluntary, ${ }^{128}$ or where the plaintiff did not actually understand the risks lie or she was assuming. ${ }^{129}$ The defense slould not be recognized, tlierefore, where sexual relations took place without proper review and approval, becausc to recognize it would violate an explicitly stated public policy.

But even when the sexual activity does follow an approved researcl protocol, courts should not recognize the defense. To do so would offend the public policy set forth in the HEW regulations which prohibit the written waiver by the subject of any of his or lier riglts, "including any release of the institution or its agents from liability for negligence." 130

In sum, iny proposals will not absolve the clinician-researcher of liability for negligence. Ratler, they are designed to permit him to sliow that sexual relations pursuant to an approved research protocol may not be negligent. If the tlerapist-investigator has not been negligent, lie will have adequate protection: the patient-subject who gives informed consent is barred from recovering im a negligence action for any injuries due to non-negligently caused risks which were disclosed to lier. ${ }^{131}$

\section{Practical Difficulties}

Even if professional organizations modified their ethical codes and

126. See id. at 440.

Although implied assumption of the risk lias lost favor in many jurisdictions, express assumption of the risk retains its vitality. See, e.g., Farley v. M M Cattle Co., 549 S.W.2d 453, 458 (Tex. Civ. App. 1977).

127. See W. Prosser, supra note 56, at 442-44 and cases cited therein.

128. Id. at $445-50$ and cases cited therein.

129. Id. at $450-53$ and cases cited therein.

130. 45 C.F.R. $\$ 46.109$ (1977).

131. See Freund, Legal Frameworks for Human Experimentation, 98 DAEDalus 314, 321 (1969); Robertson, Informing Subjects About Non-compensation, Compensating Injured Research Subjects: II. The Law, Hastings Center Rep. 29 (Dec. 1976). But see Annas, supra note 109, at 258; Adams \& Shea-Stonum, Toward a Theory of Control of Medical Experimentation with Human Subjects: The Role of Compensation, 25 CASE W. REs. L. REv. 604, 607 (1975).

This is not to suggest that $I$ am opposed to recent recommendations to establislı a compensation system not based on fault for subjects injured in research conducted, sponsored, or controlled by the U.S. Public Health Service. See United States Dep't of Health, Education and Welfare, Secretary's Task Force Report on the Compensation of InJuRed Research SUBJECTS II-2 (1977). 
courts made the adjustments discussed above, a number of potential obstacles to achieving the objectives of my recommendations would remain.

The first of these is funding. The National Institute of Mental Health finds such research mappropriate for support, ${ }^{132}$ and it would not be surprising if other sources concurred.

In addition, therapists who are not affiliated with institutions that do government sponsored or funded work may not have access to IRB review. Most IRBs feel overworked already. Moreover, the policy of some institutions to compensate subjects injured in research, even without negligence, ${ }^{133}$ might dissuade the IRBs from providing review services to outsiders. This problem could be solved if professional organizations were willing to establish a system equivalent to that required under HEW regulations, and to create reviewing bodies. ${ }^{134}$

If an IRB is available, the potential researcher will face a series of challenges in designing his project for review. Of course, there will be the research design problems that plague any attempt to evaluate the effectiveness of psycliotlierapies, such as the difficulty of measuring the outcomes ${ }^{135}$ and of coinparing patients, ${ }^{136}$ therapists, and therapeutic schools. ${ }^{137}$ Beyond those, the researcher will have to overcome the suspicion of conflicts of interest. ${ }^{138}$ But the most trymg challenge may be

132. See Brody, Sex Research Has Earned Respectability, N.Y. Times, Jan. 8, 1978, § E, at 20, col. 3.

133. At present, however, sucls a policy is the exception rather than the rule, see UNITED States Dep'T of Health, Education and Welfare, supra note 131, at III-1; that task force recently recommended that the Public Health Service issue regulations establishing a compensation system for injured subjects of PHS-conducted and PHS-sponsored researcli and that the Food and Drug Administration "consider legislation which would enable them to require that compensation mechanisms be made available to subjects mjured in the course of PHS-regulated research." Id. at II-2. For a discussion of this topic, see Robertson, supra note 131. The U.S. Department of Health, Education, and Welfare recently modified its informed consent requirements to include disclosure about the availabihty of compensation for injury. 45 C.F.R. $\S 46.103$ (c)(1-7), as amended by 43 Fed. Reg. 51,559 (Nov. 3, 1978).

134. A recently issued ethics code for sex researchers, sex counselors, and sex therapists encourages sucli persons "to arrange voluntarily to have their protocols reviewed [by an accredited IRB] and to accept the judgment of the reviewing body." Reproductive Biology Research Foundation, Ethics Guidelines for Sex Therapists, Sex Counselors and Sex Researchers, supra note 83.

Existing professional standards review organizations would not be adequate because only professionals serve on them. See 42 U.S.C. $\$ 1302$ (c)-I (1972). The same is true of ethics committees. Under the federal system of regulation of research, IRB membership must be broadly based. See 45 C.F.R. § 46.106(b)(1-5) (1977).

135. See THE BELMONT REPORT, supra note 85, at 15-1; D. MALAN, supra note 92, at 13-22; Harty \& Horowitz, Therapeutic Outcome as Rated by Patients, Therapists and Judges, 33 ARCHIVES of GeNeral Psychiatry 957 (1976).

136. See D. MALAN, supra note 92, at 191-208.

137. See M. Gross, supra note 119, at 44-45; Bergin, supra note 94, at 96; Lieberman, Yalom, \& Miles, Encounter: The Leader Makes the Difference, Psychology TodAY, Mar. 1973, at 75. Tliese authorities suggest that the style of the therapist is the most important variable.

138. Perliaps this can be accomplislied by designing the study so that the principal mvestiga- 
to develop a viable hypothesis about when and how therapist-patient sexual interaction can be therapeutic for the patient. ${ }^{139}$ Unless such an hypothesis can be formulated, no research could or should be approved.

These, however, do not seein to be insurmountable barriers. At bottom, the most difficult problem, and the crucial determination, will be the IRB's cost-benefit analysis. This will depend not only upon the extent to which the research meets the challenges described above, but also upon whether the IRB meinbers beheve that society really wants to know the impact of therapist-patient sexual relations in various situations. It may be that much of society would prefer to continue assuming that such interactions are always harmful, so as to have a utilitarian, if not an empirical, basis for their judgment that such activity is immoral. Thus, the substantial benefits of expanded knowledge about therapist-patient sexual relations may be subordmated to other, important concerns. Broadly based review boards are the appropriate bodies to undertake this weighing of interests.

\section{CONCLUSION}

Sexual relations between psychotherapists and their patients currently are condemned in the ethical codes of professional organizations and by most writers. Yet they are common. I have suggested that existing social controls are inadequate to deter or regulate these contacts, and that they affirmatively inhibit the production of information. Additionally, retrospective research efforts have yielded hittle useful data.

Prospective research could provide answers that would permit systematic study of the problein, which, in turn, could lead to a reduction in instances of harmful therapist-patient sexual activity. Moreover, a research program could help control the problein by providing a supervised forum for therapists to treat patients through sexual interaction, and by putting therapists on notice that outside such a research setting,

tor does not himself engage in sexual activity, but rather monitors the sexual activity of other therapist-investigators. This would seem to be required even for research in psychotherapy that did not involve conflict-of-imterest problems as patent as those in research on therapist-patient sexual activity. As D. Malan has written:

Any study of psychotherapy that is to be clinically useful must consist of correlation of factors in the patients (selection criteria) and in therapy (technique) on the one hand with outcome on the other. In an ideal study, there should be three independent groups of judges, eacb assessing one of these sets of variables, uncontaminated by knowledge of the others.

D. MALAN, supra note 92 , at 9.

139. For example, the only fullblown theory expounded thus far, McCartney, supra note 19, at 232, was roundly rejected. See notes $32 \& 40$ supra. The only other attempt was made by Martin Shepard, and it was too.ambiguous to be called an hypothesis. See M. SHePard, supra note 5, at 207-08. 
sexual relations with patients would not be countenanced. But this research threatens other important social values. Accordingly, I have proposed that community policy should favor the collection of such data only if it can be accoinplished under conditions that are protective of these other values, and I have suggested action by professionals, professional organizations, and the courts to permit achievement of this goal.

The quest for further knowledge about the effects of therapist-patient sexual activity poses serious risks. So does acquisition of that knowledge. Whether iny recommendations will be followed turns largely on whether society and the psychotherapeutic professions can tolerate those risks. 